\title{
THE ECO AND THE ECONOMIC DEVELOPMENT OF WEST AFRICA
}

\author{
G. Ofori-Abebrese \\ Department of Economics, \\ Kwame Nkrumah University of Science and Technology. \\ Kumasi, Ghana
}

\begin{abstract}
This paper reviews a set of key issues arising in the context of the prospective monetary integration of West African countries into a single currency zone. It examines the economic arguments relating to the timing of a future adoption of a single currency by the West African states. In doing so, the analysis pertains to the prospects for meeting the convergence criteria set in a sustainable manner, particularly highlighting on the, contemporary parameters that can be considered instrumental in the strategic decision to introduce a single currency in the sub-region. The paper concludes that, on balance, if the intermediate arrangements, such as the convergence criteria set and the establishment of independent supranational central Bank work out well, then complete economic integration of the sort as envisaged in the original ECOWAS treaty could possibly ensue. However, looked at from the perspective of the West African economies, as relatively weak with fragile structures and almost all these countries depend on donor funds to finance their budgets, the risk that member states of Eco could turn inward in a way that is destructive of the monetary union is quite real and hence limits the success of monetary integration in the sub-region. This means that participating member states must work diligently to achieve a high degree of sustainable convergence in terms of low inflation and sound public finances. Macroeconomic policy surveillance and peer group pressure should follow provided guidelines and sufficient political will should override national short-term interest.
\end{abstract}

Keywords: Monetary integration; Convergence criteria; Fiscal policy; Monetary policy; Single currency.

\section{INTRODUCTION}

One of the most significant developments in West Africa over the last three decades has been the formation of Economic Community of West African States (ECOWAS) in 1975. The main objective of (ECOWA) in accordance with articles 3 and $51-55$ of its treaty was to create an economic and monetary union for promoting economic growth and development in the West African sub-region. These included, inter alia,

124 journal of science and technology, volume 26 no. 2, August, 2006 
the elimination of tariffs and quotas on the import and export of goods between member countries, the establishment of a common external tariff, the abolition of obstacles to the free movement of people, services and capital between member states and the establishment of common policies for agriculture and transport.

ECOWAS members include Benin, Burkina Faso, Cape Verde, Cote D'Ivoire, The Gambia, Ghana, Guinea, Guinea-Bissau, Liberia, Mali, Niger, Nigeria, Senegal, Sierra Leone, and Togo. Monetary integration' has been figured as an important element if ECOWAS should thrive to achieve its objectives. This development in West Africa mirrors what has been taking place in the world economies where regional economic groupings have restructured their economies to enjoy the benefits of monetary union.
While the specific justifications for monetary union are debated, there is general agreement that they are framed by g lobalization and competition. The growth of world trade, a direct outcome of the internationalization of the economy, has made it essential for countries to come together to extend their market coverage.

This paper presents an overview of the process of West African Monetary Union and its implications on the economic growth on member states. It focuses on three features; the evolution and transformation of West African Monetary Union, economic benefits and challenges of the Eco and the economic performance and projections of member states.

\section{Evolution and Transformation of the West African Monetary Union}

The importance of international monetary coop-

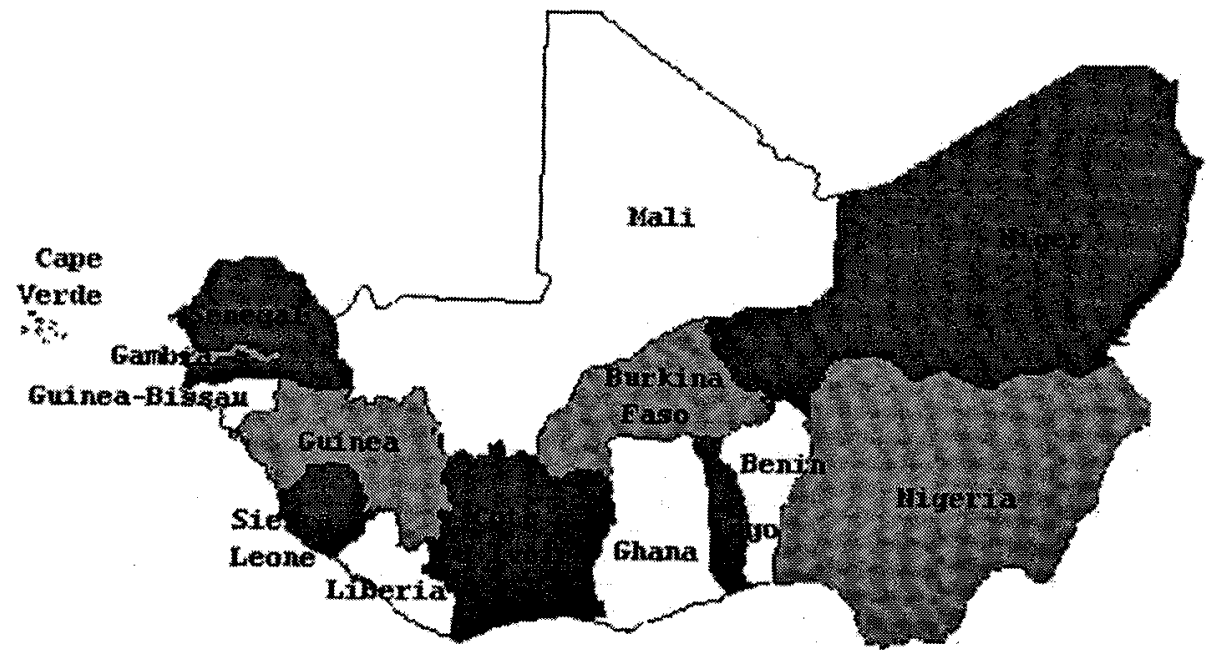

Figure 1: Member States of ECOWAS

\footnotetext{
${ }^{\prime}$ Monetary integration is an integral component of economic integration. It is an evolutionary process that culminates in the adoption of a common monetary policy by a number of countries ceding sovereignty on monetary matters to a common monetary authority responsible for issuing a single currency. Monetary integration may evolve through a number of cooperation arrangements like, an exchange rate arrangement where limited currency convertibility exists, parallel currency union where national currencies co-exist with a common currency, and a full monetary union where a common central bank exists to formulate and implement a common monetary policy and issue a single currency. It establishes a pegged central value for currencies which can fluctuate vis-à-vis each other within a narrow band around that central rate.
} 
eration has been recognized for a long time in West Africa. In some cases the need for international co-operation was regarded as very essential for economic development that it resulted in the establishment of permanent organizations. For example, among the Anglophone countries, Nigeria, Ghana, Sierra Leone and The Gambia, the West African Currency Board was established in 1912, charged with the issue and redemption of West African currency. They had common currency West African Pound. Among the Francophone countries, the Union Monetaire de l'Afrique de l'Ouest (West African Monetary Union, UMAO) was formed in May 1962 by Dahomey (now Benin), Ivory Coast (Cote D'Ivoire), Mali, Mauritania, Niger, Senegal and Upper V olta (now B urkina $\mathrm{F}$ aso). The UMAO, joined by Togo in November 1963, was one of the few examples of complete monetary unions in the world. It integrated the monetary sy stem of the eight participating countries under one central bank, namely the Banque Centrale des Etats de l'Afrique de l'Ouest (BCEAO) commonly refer to as the CFA Franc Zone. The CFA Franc zone made explicit their intention to strengthen their political, economic and monetary solidarity and reaffirmed their commitment to the Franc Zone by the establishment of the West African Economic and Monetary Union (WAEMU) in 1994.

Consideration for monetary union has remained a c entral e lement in ECOWAS' d iscussion and negotiation for sometime now. A regional central monetary institution is envisaged to harmonise economic and monetary policies, liberalise trade in the region, supervise members' balance of payments, provide members with better access to the resources of the primary international institutions and also offer the community a better instrument at the world's collective bargaining table. A special function of such an institution would be to offer advice and guidance to the whole region on monetary matters on the $b$ asis of the study of the special conditions and needs of the community. Looking at the annals of the countries in the community, it was prudent for a common convertible currency to be adopted to facilitate regional trade transactions by improving and strengthening regional payments and clearing system.

- Promote the use of the currencies of the members of the Clearing House for sub regional trade and other transactions.

- Bring about economies in the use of foreign reserves of the members of the clearing House.

- Encourage the members of the clearing house to liberalise trade among their respective countries and

- Promote monetary cooperation and consultation among members of the clearing house and facilitate economic activities and harmer home the required expectations of ECOWAS.

However, in its first decades, a significant number of obstacles to the freedom of people, services and capital between member states, and thus competition on equal terms, still remains. The WACH could not live to fulfil its obligations. A committee was therefore set up to examine and redefine the objectives and activities of WACH to address and adapt to the economic trends in the region. It was decided that WACH be transformed into a specialized agency of ECOWAS and this was a dopted by the G overnors in February 1992 and approved by ECOWAS Heads of States in July 1993. This culminated in the establishment of the West African Monetary Agency (WAMA) in 1994 to;

- Promote monetary cooperation and payment issues within the context of the economic and monetary integration of the region.

- Initiate and promote policies and programmes for achieving monetary integration.

- Facilitate the harmonization and coordination of economic polici and structural adjustment programmes of member states and ensure the establishment of a single monetary zone (African Development Report 2000). 
To expedite the ECOWAS integration programme, the Heads of State and Governments of The Gambia, Ghana, Guinea, Liberia, Nigeria and Sierra Leone, acting within the ECOWAS framework of regional integration, signed in Accra on $20^{\text {th }}$ April 2000 a declaration on the creation of a second Monetary Zone. The Second Monetary Zone was formally launched and named the West African Monetary Zone (WAMZ) $^{2}$ at the Bamako Mini-Summit of Heads of States and Governments of member countries in December 2001. All the above countries except Liberia signed the statute of WAMZ. The West African Monetary Institute (WAMI) was established at that meeting to undertake all necessary tasks leading to the setting up of the West African Central B ank (WACB) and the introduction of a common currency. As a follow up, the Treaty of Accra was signed in February 2002 to promote the single. West African market by encouraging the removal of remaining barriers to trade and increasing integration by replacing national currencies with a single West African currency to be known as Eco. It set out a timetable for the monetary union and the introduction of single currency (ECO) to be achieved in three stages. Stage one is already in progress with the move towards a single market. The main features of stage two were to be increased co-ordination of national monetary policies and encouragement for governments to achieve greater similarity of economic performance (convergence). The third stage was to be the establishment of the West African Central Bank and the introduction of the single currency.

The five Anglophone ECOWAS members committed themselves to restructure their economies to meet the stringent macroeconomic convergence criteria ${ }^{3}$ ahead of the introduction of a single currency. While considerable progress had been made in the preparation of policy frameworks and architecture for the WAMZ Monetary Union, developments in the economic performance of member states have not been very satisfactory. As at the end of June 2002, only one member country, The Gambia, satisfied three of the four convergence criteria, two countries satisfied two convergence criteria each, while two other countries satisfied only one criterion each. The WAMZ Monetary Union programme still has some way to go.

\section{Economic Benefits and Challenges of the Eco}

Introducing a common currency bears with it economic benefits as well as challenges, which can be weighed against each other to determine the economic rationale for aiming for monetary unification for a given region. These benefits and challenges are given by the theory of Optimum Currency Areas (OCA). OCA theory identifies certain criteria that a region should fulfill for it to be economically optimal to let go of the adjustment tool of a national currency. These criteria include whether the countries have similar production and trade patterns, whether economic supply and demand shocks are likely to be asymmetric across the countries and whether economic cycles are symmetric across borders. The set of OCA criteria is very restrictive. However, it has often been argued that once a common currency is introduced, the synchronization of economic cycles will follow due to the derived boost of trade integration.

The theory of monetary integration postulates a wide array of channels through which the impact of the monetary union on the economies sharing a common currency may be exerted. In this study only three, namely potential transaction

\footnotetext{
${ }^{2}$ WAMZ is an institutional cooperative framework for achieving monetary union under the commitments made in the "Accra Declaration" signed by six countries in West Africa on the establishment of a second monetary zone.

${ }^{3}$ There are two main types of convergence, both of which are important. One is cyclical convergence. This is achieved when member countries 'economic cycles coincide. The other is structural convergence. This involves the economic structures of the member countries being similar. Structural convergence should mean that the economic cycles of the member countries continue to move in line for years to come.
} 
savings, effects on interest rates and bilateral trade expansion, are considered. Foregoing an independent currency will bring about significant gains in Gross Domestic Product (GDP) growth through the following key channels: reduced transaction costs, expansion of foreign trade, a drop in real interest rate and the easing of the current account constraint. In addition, by joining monetary union, the countries would be less vulnerable to sudden reversals of capital flows, which make the implementation of independent monetary policy more costly and less successful than a more or less appropriate imported policy. This will provide a tentative assessment of the long-run growth effects that would be triggered by these channels.

Hence, the switch to the Eco is expected to provide a stimulus for bilateral trade between member states in WAMZ. One factor behind the bilateral trade expansion is the elimination of transaction costs that constitute a non-tariff barrier to foreign trade. However, it should be noted that the importance of this factor will largely depend on the extent to which these savings translate into lower prices of tradable goods.

Once in the WAMZ, the bilateral exchange rate would cease to exist and the related costs such as commissions, s preads between buying and selling rates, fees for hedging against exchange rate risk and in-house costs would be eliminated. Assuming that resources released a s a r esult of elimination of transaction costs find an alternative use, transaction cost savings represent a one-off rise in overall efficiency with which capital and labour are matched to produce a unit of output.

The potential growth bonus arising from the trade expansion is likely to be a combination of two factors. The first are the traditional gains from specialization driven by exploitation of the economies of scale. The second growth component is postulated by the new trade theory based on models with endogenous technological change (Grossman and Helpman, 1991; Ed- wards, 1997). In these models, foreign trade acts as an important carrier for knowledge spillovers and absorption of technological progress achieved by other countries. As a corollary, the total factor productivity in more open economies should grow faster than in countries less open to foreign trade.

Using a gravity model of trade to assess the effects of currency unions on trade, Frankel and Rose (2000) conclude that, the benefits arising from the introduction of a single currency come chiefly through the promotion of trade rather than lower interest rates. They applied a twostage approach to estimate the impact of currency unions on output and their chief finding was that, participation in the common currency area more than triples trade between the countries sharing a common currency.

Further, the take off of the Eco would eliminate the currency risk premium required by riskaverse investors. This static efficiency gain induces capital formation (dynamic efficiency gain) that eventually magnifies the initial rise in output per capita (Baldwin, 1991). The attendant rise of the risk adjusted rate of return (equivalent to the fall of the risk-adjusted discount rate) is likely to boost domestic investment in member countries, which, in turn, will foster capital formation and output per capita (Baldwin, 1991)

Other gains, such as welfare gains from low inflation, higher competition arising from greater price transparency and efficiency gains from capital market integration are also relevant to the long-term growth potential of the member states. The in-house costs embrace, inter alia, resources tied up in managing foreign exchange operations, exchange rate risk exposure, maintaining additional accounting activities and losses due to less efficient cash management. Elimination of exchange rate uncertainty may provide a potential stimulus to foreign direct investments.

The question is: will the policies embodied in the West African Monetary Union produce the 
expected results? In many cases these polices, after more than a decade of implementation, are beset with a number of challenges and have not fulfilled all their promises. There are many reasons for this poor performance.

In the first place, member countries face the challenging decision on the speed of convergence to the WAMZ. A fundamental policy question is whether member countries should aim for rapid convergence and whether this will hurt their growth performance.

From a monetary policy standpoint, real convergence required by introduction of the Eco can be best analyzed within the optimal currency area (OCA) theory framework. According to OCA theory, pioneered by Mundell (1961), McKinnon (1963) and Kenen (1969), an independent monetary policy and the exchange rate instrument are necessary stabilization tools for alleviating the impact of a symmetric sh ocks for a region. The five major OCA criteria are openness, trade integration, cyclical harmonization and structural similarities of the economies; and the flexibility of labour and goods markets.

As the term implies, monetary unification requires an irrevocable locking of nominal exchange rates and the establishment of a common central bank. Monetary policy is to be determined centrally. In a monetary union, there is no option for adjusting the exchange rate parities to misalignment caused by differential inflation rates or supply or demand shocks hitting the region in an asymmetric manner. Also under monetary unification, the national governments have to be ready to delegate monetary policy entirely to the politically independent supranational and central monetary authority. Monetary unification hence implies independence of the monetary policy from the influence of national fiscal authorities.

At the start of the monetary union, contrasting expectations and fears were raised about the consequences of strict adherence to a system of fixed, though adjustable, exchange rates on eco- nomic developments and policies of participating countries. There was concern that the constraints of a fixed exchange rate system would force countries with higher inflation rates to turn to overly restrictive policies in order to ward off excessive losses of reserves. It seemed unreasonable to expect countries with highly divergent economic developments to be able to align their policies to the degree necessary to keep a system of fixed exchange rates functioning.

Besides, the success or otherwise of the ECOWAS as a trading bloc will depend in large part on the extent of convergence and integration. The greater the degree of convergence, the more likely it is that the pursuit of common policies, including a single currency and interest rate, will benefit all economies. If all members have similar economies and react to the external shocks in a similar way, it should be relatively easy to decide on, for example, one interest rate for the whole area. If, however, the economies differ in a notable way, as is the case now, then different policy measures might be needed for each economy. Applying the same measure in such a situation is likely to result in some economies becoming deflated while others become overheated.

Moreover one of the main criticisms to the convergence criteria set is based on the so-called "one size fits all" nature of the policy. The interest rate decided by the West African Central Bank applies to all the countries in the WAMZ. There is a risk that an interest rate that may be appropriate for the area as whole may be inappropriate for some individual member countries. Those member countries with overheating economies and high inflation will have low real rates of interest when they need high real interests, while economies with high levels of unemployment and low inflation will have high real interest rates. If all the economies were operating at a similar point in the economic cycle, having the same interest rate would not be a problem. In practice however, there are still significant differences in the WAMZ economies. 
The convergence criteria are geared towards stability both at home and abroad. Stability abroad is equivalent to exchange rate stability and stability at home means domestic monetary developments are consistent with stable domestic cost and prices. The stability of exchange rates, cost and prices is seen as essential precondition for further economic integration in the sub-region for economic a nd for the narrowing of differences in the standards of living.

This means that, a limit has to be placed on the budget deficits that governments can operate in a single currency to ensure price stability and economic growth. It is true that, if a government, or group of governments, operates large budget deficits they will a dd to a ggregate demand and possibly the money supply. This is likely to put downward pressure on the Eco that may generate inflationary pressures and result in a higher rate of interest for all member countries.

One should also not lose sight of the fact that fiscal policy is strongly influenced by the political cycle in member countries. As a result, the credibility of fiscal commitment is a channel where contagious effects may work themselves through. The convergence criteria incorporate a monetary policy assignment problem, as low inflation and stable exchange rate have to be accomplished simultaneously. Since tight monetary policy may invite large capital flows inducing undesirable changes in the exchange rate, the optimal solution would be achieving disinflation with fiscal measures. Monetary policy would solely be responsible for the stabilisation of the exchange rate. As convergence brings about significant easing in longer-term interest rates, reaching the inflation target may require even more substantial and unpredicted adjustments on the fiscal side than compliance with the preset convergence path. Increasing the burden of fiscal policy during the period of large-scale consolidation and expecting timely adjustments in a wake of unpredicted shocks is unrealistic. Consequently, the tasks of exchange rate and price level stabilisation should remain dual objectives of monetary policy. Accordingly, a robust c onvergence strategy should leave manoeuvring room for both monetary and fiscal policy.

Moreover, there is a tendency for a reduction in independence of macro-economic policy by the individual member states. In addition to no longer being able to operate its own interest rate, the individual countries would lose the independent exchange rate policy or monetary policy for their countries. Countries would no longer be able to increase the 1 oney supply in order to spur output and emp. yment. Countries would no longer be able to ursue independent inflationary policies in ore $: r$ to collect seigniorage ${ }^{4}$ to cover governments deficits and would have constraints imposed on its use of fiscal policy. WAMZ member countries' choice of government policy measures will be constrained by their membership of the single currency. Monetary policy will be in the hands of the West African Central Bank. Member states can use expansionary fiscal policy to stimulate aggregate demand and raise employment. However, government's use of fiscal policy is restricted by the Convergence Criteria. When a government employs expansionary fiscal policy, its spending will rise relative to tax revenue. This may result in a budget deficit but the Convergence Criteria requires national governments to keep their budget deficits below $4 \%$.

Again, the important benefit joining a monetary union comes from the 'dynamic effects' on investment and growth (Baldwin, 1991). Unfortunately, these large effocts are uncertain and depend on how a counlly creates opportunities. Empirical estimates of these effects vary widely and a re sometimes close to zero. Presently, we understand little about the size of the long-term net benefits, or how long it will take for these

\footnotetext{
${ }^{4}$ Seigniorage in this paper refers to the revenue that accrues to the issuer of money. This applies to the net revenue derived by any money-issuing body.
}

130 journal of science and technology, volume 26 no. 2, August, 2006 
benefits to materialize. Care should therefore be exercised in advertising that there will be sizable benefits from monetary union, as the potential benefits are not automatic and will take time and effort to develop.

The other related problem is implicit in the fact that these countries have given different weights to the economic problems they face. It is a strong indication that the risk of asymmetric shocks may be much more pronounced than usually expected. Under these conditions, much more effort and flexibility will be needed to adjust economic structures. Care must be taken in analyzing the differences between countries and in d rawing $\mathrm{g}$ eneral $\mathrm{c}$ onclusions from this a bout the integration process.

At the same time, output volatility would be high in catching-up economies. In real convergence $s$ ettings, therefore, it a ppears $p$ articularly important to assess the output volatility implications of different policy frameworks and opt for arrangements that contain such variability. There are a number of theoretical arguments as to why high volatility in output may have negative effects on long-term growth. These arguments relate to skill losses (Martin and Rogers, 1995), increased political uncertainty (Alesina and Ardagna, 1992), credit-market imperfections (Stiglitz and Weiss, 1992) and the postponement of investment decisions in times of uncertainty (Dixit and Pindyck, 1994). The empirical literature tends to validate these theoretical propositions (Ramey and Ramey, 1994; Martin and Rogers, 2000).

Unemployment is a significant issue for ECOWAS and a major cause of this high unemployment is thought to be the lack of labour market flexibility. Individual member countries would seek to reduce unemployment although the measures that members of the WAMZ can take would be constrained by their membership with the single currency.

Another cause of unemployment in WAMZ is claimed to be low savings in the individual countries. This implied that access to domestic employment-enhancing investment capital is limited. The aspirants to membership of the single currency will introduce deflationary fiscal and monetary policies in order to meet the convergence criteria that are likely to worsen the unemployment situation.

The authorities trying to solve the twin problems of high unemployment and inflation are working tirelessly to bring in investment capital from foreign sources. Foreign Direct Investment has been encouraged and nurtured by the authorities by granting various tax concessions. This results in a development dilemma. On the one hand, unemployment is high and there is a need for employment-increasing measures by inducing foreign investments due to low domestic savings. On the other hand the net out flow from such policies results in low revenue to support government budgets to increase employment.

Concern has a lso been $r$ aised regarding foreign direct investment (FDI) flows. Not all countries in the sub-region have experienced an increase in F DI flows. W hile the monetary union might bring more FDI, the benefits are not always evenly distributed. They are generally likely to be concentrated in countries with large domestic markets that are used as platforms to "export" to other member states. In this circumstance, some countries might even experience disinvestments in their territories.

Further, greater reliance on international capital flows and the increasing mobility of intraregional capital flows can fuel macroeconomic instability. W ithout a dequately p reparing financial and other institutions for large capital inflows, crisis situations may become more frequent in the ECOWAS region in the future. It would lead to rapid consumption growth, rising or sustained high inflation, an appreciating real exchange rate and widening current account deficits (Schadler, 1994). Corker et al. (2000), also argue that a surge in foreign capital inflows 
adds a potential new source to higher inflation rates.

An issue that a lso deserves a ttention is the i mpact of World Bank/IMF and the international debt crisis on the member countries' policy space. That is the scope they have to decide on their own domestic policies. Many of the West African countries have some years suffered acutely from poor export growth and deteriorating terms of trade. Most have not had access to commercial credits and, in recent years received limited, increases in real flow of official development assistance. As a result many West African countries have experienced acute financial crisis. Problems have been encountered in servicing official, largely bilateral debt and in paying for imports already received. Import growth compression has severely disrupted production for domestic and export markets and the purchase abroad of supplies vital for meeting basic social needs. The resulting shortage have fuelled domestic inflation and put considerable pressure on government budgets and general living standards. An obvious symptom of these crises is the increasing frequency with prices of petroleum products and the rate with which countries under the West African Monetary Union are turning to the IMF for assistance. At the same time the World Bank has its approach by making its own innovative structural adjustment loans, for example HIPC, a form of balance of payments support conditional upon prior acceptance by borrowers of an IMF adjustment program.

The World Bank and the IMF programs therefore exercise, and will continue to exercise, an important influence on the economic policies of the West African nations.

\section{Economic Performance and Projections of Member States}

The member states preparedness for the take off of the Eco should be assessed both in terms of real and nominal convergence. The level of real convergence reveals whether joining WAMZ will increase or mitigate the volatility of busi- ness cycles, and whether the monetary policy in WAMZ is capable of taking the place of independent monetary policy of the various countries in smoothing out cyclical fluctuations.

Nominal convergence means the fulfillment of the Convergence criteria in terms of a low and stable inflationary environment, su stainable fiscal position and exchange rate stability. The table below briefly summarizes the member countries' current position in the nominal convergence process.

Table 1: Economic indicators of selected member states

\begin{tabular}{lcccc}
\hline Country & $\begin{array}{c}\text { Inflation } \\
\text { Rate }(\%)\end{array}$ & $\begin{array}{c}\text { Budget } \\
\text { Deficit }(\% \\
\text { GDP) }\end{array}$ & $\begin{array}{c}\text { GDP } \\
(\%)\end{array}$ & $\begin{array}{c}\text { Foreign } \\
\text { Reserve } \\
\text { (US \$ M) }\end{array}$ \\
\hline Gambia & 16.7 & N/A & 6 & 70 \\
Ghana & 12.4 & 22 & 5.4 & N/A \\
Guinea & 17 & N/A & 1 & 181 \\
Sierra & 12 & N/A & 6 & 68.1 \\
Leone & 16.7 & 1.6 & 4.4 & N/A \\
Nigeria & & & & \\
\hline
\end{tabular}

Source: Data from Economist Intelligence 2004

It could be deduced from the table above that none of the five countries has met the criterion for single digit inflation for the take off of the single currency, the Eco. With a required inflation rate of $5 \%$ by 2003 , it is only Sierra Leone that has an inflation rate of $12 \%$ and the IMF attributes this to donor support due to their emergence from war in its Country Report for May 2004. Nigeria, the e conomic g iant in the group has an inflationary rate as high as $16.7 \%$. It is expected that fuel price rises will work their way through the economy only by late 2005 . Even then, it is not likely the government would find it easy to push inflation down, as spending will remain high, particularly in the second half of 2006 in the run-up to the elections, a nd monetary policy will remain quite loose, given the pressure on the Central B ank of $\mathrm{N}$ igeria $n$ ot to raise interest rates. As a result, inflation is unlikely to fall into single digits for the take off 
of the Eco. Macroeconomic imbalances continue to persist in Nigeria, the total public debt amounted to N 5.6 trillion, equivalent to $74 \mathrm{1} / 2$ percent of GDP at end of 2003. Total domestic debt amounted to $\mathrm{N} 1.3$ trillion (about 18 percent of GDP) at end-2003 (Economist Intelligence 2004)

Though Guinea outperformed the West African Monetary Zone (WAMZ) member countries between 1998 and 2002, it however, in 2003, became the worst performer in the regional context, except for higher average inflation in WAMZ countries due to the rapid price increases in Ghana, rapid growth in broad money, which brought the 12-month rate of inflation (CPI-based) to 14.8 percent in December 2003 (from 6.1 percent in December 2002). According to IMF Article IV consultation, staff report, May 2004 , inflationary pressures eased somewhat, to 9.4 percent year-on-year, owing to temporary factors, including an unsustainable freeze on domestic petroleum product prices.

Revenue fell short of $1 \%$ of GDP and expenditure overrun by $1 \frac{1}{2} \%$ of GDP and this widened the fiscal deficit from 4.4\% of GDP in 2002 to $5.1 \%$ of GDP at the end of December 2003. In the absence of external budgetary assistance, this deficit was financed by an accumulation of arrears and by increased borrowing from the banking system. Budget implementation in the first quarter of 2004 was poor. Revenue registered a $0.6 \%$ of a nnual GDP s hortfall d ue to p oor collection efforts and use of an overvalued exchange rate to value imports. The net foreign assets of the central bank declined and were negative at end-December 2003, at US\$ -10.4 million. (Economist Intelligence 2004)

Notwithstanding the deterioration of Guinea's performance with regard to the convergence criteria of WAMZ, and the difficulties Guinea might encounter to adjust to asymmetric exogenous shocks in the envisaged monetary union, the authorities reaffirmed their commitment and to adhere to WAMZ monetary union when launched on July 1, 2005.
In Sierra Leone, real GDP growth rose by 4 percent in 2000 and accelerated further in 2001 and 2002 to 18 and $271 / 2$ percent, respectively. Real GDP for 2003 rose by 9 percent. Inflation stabilized following the end of the conflict, but inflationary pressures reemerged in 2003. After the signing of the peace accord in July 1999, annual average inflation fell sharply from nearly 34 percent in December 1999 to -1 percent in December 2000 . As the supply situation improved, macroeconomic policies were tightened, and the exchange rate appreciated in real terms in 2000. Inflation remained low in 2001 and 2002. Gross official reserves of the Bank of Sierra Leone have been under pressure. The import cover peaked at 2.5 months in 2002 , but declined to 1.5 months by end-2003.

During this period, the government's fiscal performance was also generally w eak. Overall fiscal deficits averaged 7.5 percent of GDP (Economist Intelligence 2004)

In Gambia, fiscal deficits (excluding grants) were 8.1 percent of GDP in 2002 and 6.0 percent in 2003, and it increased to 15 percent of GDP in 2004. Real GDP is estimated to have grown by 8.8 percent in 2003, CPI rose by 18 percent during 2003. Of late, exogenous and endogenous shocks have severely strained The Gambian economy, manifested by a depreciation of the domestic currency and rising inflation. The Government of The Gambia is, however, committed to restoring macroeconomic stability. To this end, a cash budget was recently introduced effectively tying expenditure to revenue. Other key fiscal reforms implemented include public expenditure reviews and fiscal "flash" reporting system, amongst others. In addition to prudent fiscal policies, a tight monetary stance would be pursued for the foreseeable future in order to contain inflation and strengthen external reserves.

According to IMF Country Report on Ghana in May 2004, the performance criterion on (zero) net domestic financing of the budget for 2002 
was observed. This implied a sharp reduction in the burden of domestic debt relative to GDP to below 20 percent in 2003, from just over 26 percent a year earlier. The inflows of foreign exchange brought gross international reserves to almost 4 months of imports at the end of 2003 , compared with about 2 months at end-2002. Domestic debt service declined from about 2.2 percent of GDP in 2002, to 1.4 percent in 2004 due to fiscal discipline and increasing confidence in monetary policy implementation. Progress has also been made on structural reforms, in particular, in enhancing public expenditure management, strengthening the operating framework of the central bank.

The idea behind these criteria is that countries must have a chieved a $h$ igh d egree of monetary policy convergence and a controlled fiscal position (small deficit and low debt) to make them qualify for the monetary union.

However, none of the member countries has satisfied the convergence criteria as at October 2004. Ghana for instance, with high public debt levels, will be unlikely ever to meet them. As a result, the criteria may be relaxed as the reality of a single currency comes closer. There are always shocks to the real economy that blow convergence off course so convergence can never be guaranteed to arrive within a given time-scale.

Although WAMZ membership would bring about significant welfare gains in the longer term, meeting the nominal $\mathrm{c}$ onvergence $\mathrm{c}$ riteria requires further adjustment both in inflation and fiscal position, which may entail economic costs related to the speed of the convergence process. Meeting the inflation criteria requires further efforts from economic policy. Member countries have not yet achieved an established lowinflation environment. The results of rapid disinflation appear to be rather fragile as they may be accompanied by appreciation of the currency, and households' inflation expectations are still stuck in double-digit range.

\section{CONCLUSION}

This $p$ aper has highlighted so me of the key issues arising in the context of the prospective monetary integration of $W$ est $A$ frican c ountries into a single currency zone. The introduction of a common currency bears with it economic benefits as well as challenges, which can be weighed against each other to determine the economic rationale for aiming for monetary unification for a given region. These benefits and challenges are given by the theory of Optimum Currency Areas (OCA). OCA theory identifies certain criteria that a region should fulfill for it to be economically optimal to implement the adjustment tool of a national currency. These criteria include whether the countries have similar production and trade patterns, whether economic supply and demand shocks are likely to be asymmetric across the countries, whether economic cycles are symmetric across borders.

Two components seem to be required for the successful introduction of the single currency. First, it is crucial that participating member states work diligently to achieve a high degree of sustainable convergence in terms of low inflation, sound public finances and exchange rate stability. Secondly, the existence of prolonged periods of macroeconomic stability, during which policy makers do not have to conduct day-to-day macroeconomic crisis management and instead can focus on longer-term priorities.

The paper concludes that, on balance, if the intermediate arrangements, such as the convergence criteria set and the initial arrangements to establish central monetary authority work out well, then complete economic integration as envisaged in the original ECOWAS treaty with monetary union could possibly ensue. This, however, depends p rimarily on the smooth and orderly process of the countries' ability to control their budget deficit nd inflation to promote economic growth. These asic considerations are often in conflict with respects to Eco member states. The West African countries have faced, and continue to face, acute financial crises with 
very real and debilitating effects on an economic growth, human welfare and development potential.

As relatively weak economies with fragile structures, they have not had access to significant amounts of revenue, they have low savings capacity and therefore relatively more dependent on donor funds or official development assistance and, increasingly, credits from the International Monetary Fund (IMF) and the World Bank for the foreign exchange and revenue support needed to maintain their economic growth. Most West African countries will therefore have to depend on the developed economies to achieve growth target. Almost all these countries depend on external inflows to finance their budgets and the effects of external inflows cannot be o verlooked when considering the reduction of inflation and debt. The risk that member states of Eco could turn inward in a way that is destructive of the monetary union is real.

What then are the options for cooperating on lowering macroeconomic instability to achieve the set goals, given the economies of West Africa and lack of success of previous attempts? Two things are essential for macroeconomic policy coordination to be implemented and successful. First, it is important that policy makers in the region understand that macroeconomic policy cooperation is a positive sum game and that all countries in the region stand to miss out in terms of potential welfare-enhancing trade integration if further delayed. Only from such an understanding does macroeconomic policy cooperation become feasible in the ECOWAS region.

Second, consensus targets for macroeconomic variables such as deficits and public debt ratios, and further, exchange rate policies, should be identified and guidelines should be provided for macroeconomic policy surveillance and peer group pressure to follow the provided guidelines as well as sufficient political will to override national short-term interest. Such cooperation may be the i nitial first s tep that paves the way for future agreements.
The evidence suggests that, monetary cooperation in the ECOWAS region should be gradual. A first step is to set up, at a very minimum, guideline for the exchange of information on macroeconomic developments between governments or other relevant authorities. Moreover, this step is straightforward to implement, and the natural framework for institutionalizing such initiatives would be within the ECOWAS treaty, with a specific reference to the aim of enhancing monetary unification among ECOWAS member countries.

\section{REFERENCES}

African Development Report (2000), Regional Integration in Africa published by African Development Bank

Alesina, A. and Ardagna, S. (1992): Political instability and economic growth, NBER Working paper no. 4173.

Baldwin, R. ( 1991): M easurable d ynamic gains from trade, Journal of Political Economy 100(1)

Corker, R. Beaumont, C. Van Elkan, R. and Iakova, D. (2000): Exchange Rate Regimes in selected advanced Transition Economies: Coping with Transition, Capital Inflows, and $\mathrm{EU}$ accession, IMF policy discussion paper no. 3, April.

Dixit, A, and Pindyck, R. (1994): Investment under Uncertainty, Princeton University Press: Princeton, NJ.

Economic Intelligence 2004, published by IMF.

Edwards, S. (1997): Openness, Productivity and Growth: what do we really know, NBER Working paper 5978.

Frankel, J.A and Rose, A.K. (2000): Estimating the effect of Currency Unions on Trade and Output, NBER Working Paper 7857.

Grossman, G.M and Helpman, E. (1991): Trade, knowledge spillovers, and growth, European Economic Review 35: 517-526 
Kenen, P. (1969): The theory of Optimum Currency Areas, In Mundell RA, and Swoboda AK (ed). Monetary Problems in the International Economy. University of Chicago Press: Chicago. Pp 41-60

Martin, P. and Rogers, C. (1995): Long-Term Growth and Short-Term Economic Instability, CEPR Discussion paper no. 1281, November.

Martin, P. and Rogers, C. (2000): Long-Term Growth and Short-Term Economic Instability, European Economic Review 44(2): 359-381.

McKinnon, R.I. (1963): Optimum Currency Area, The American Economic Review September: $p p .717-725$.
Mundell, R.A. (1961): A Theory of Optimum Currency Areas, The American Economic Review 51(4): and 657-665.

Ramey, G, Ramey, V. (1994): Cross-country evidence on the link between volatility and growth, NBER Working paper no. 4959, December.

Schadler S. (1994): Surges in Capital Inflows: Boon or Curse, Finance and Development, March.

Stiglitz, J, Weiss, A. (1992): Asymmetric Information in Credit Markets and its implications for Macroeconomics, Oxford Economic Papers 44, 694-724.

World Bank Country Report May 2004. 